\title{
Self-Efficacy, Anxiety Level, and Research Attitude of Pre- Service Teachers
}

\author{
Dr. Alma M. Natividad, Mr. Jefferson Mangulabnan and Dr. Jean R. Canlas \\ Holy Angel University, School of Education, \\ Angeles City, Philippines
}

\begin{abstract}
The aim of conducting this study is to identify and describe the level of self-efficacy, level of anxiety and attitude toward research of the third year pre-service teachers. Employing the descriptive crosssectional method of research, a survey questionnaire developed by the researchers based on the questionnaire adapted from Ozturk Confirmatory Factor Analysis of the Educators' Attitudes toward Educational Scale and Papanastasiou's Attitude Toward Research (ATR) Scale was administered to 154 pre-service teachers. The results of the study revealed that the students taking Methods of Research in Education have a high level of anxiety in conducting research; they have an average self-efficacy or one's ability to perform specific research activities and have positive attitude toward research. Furthermore, the data showed that there is no significant relationship between level of anxiety and level of self-efficacy towards research of the respondents. Likewise, the results also show that no significant relationship exists between research self-efficacy and attitude towards research and level of anxiety and attitude towards research of respondents. However, a significant relationship exists between respondents' self-efficacy and respondents' attitudes towards research. Results were utilized for the innovation of the programs and activities to improve the self-efficacy and attitudes of the respondents toward research.
\end{abstract}

Keywords: self-efficacy, attitude, level of anxiety, research, pre-service teachers.

\section{Introduction}

According to the latest Project Information Literacy Progress Report (2010), 84\% of students lack basic research skills. This is a truism despite information explosion in the internet. This is also the observation of the teacher-researchers among their students since they have been teaching research subjects for a long time.

According to Creswell (2008), research is a process to collect and analyze information to increase understanding of a topic or an issue. It consists of three steps: posing a question, collecting data to answer the question, and presenting an answer to the question. Research provides learning opportunities that are beyond traditional coursework. Through research work, knowledge is reinforced and assimilated and students are provided with better understanding of and deeper appreciation for the discipline under investigation and given opportunity to apply that knowledge. Recently, Higher Education Institutions (HEIs) have given focus on research, making it a vital part of university function aside from the traditional task of teaching (Etzkowitz, 2003).

Holy Angel University (HAU), as an HEI and as a research intensive university, aims to help students develop their research skills and build research culture among students and faculty. A culture of research provides a supportive context, in which research is uniformly expected, discussed, produced, and valued (Cheetham, 2007). This culture of research among students is developed through their subject Research Methods in Education of all across the University's program offerings. The course deals with the basic educational research concepts and principles aimed at equipping graduating students with skills and tools for systematic investigation. Research 
also provides rewarding learning experiences for students and producing graduates capable of high personal and professional achievement. And to achieve this, students must develop a positive attitude towards research work or activities (Sadiah \& Abiodullah, 2014).

In the Teacher Education Department of School of Education of HAU, the Research Method in Education is one of the professional education subjects that a student must pass to complete the degree in the baccalaureate course. This subject comprises 6 units and it is taken by students in their junior years. Two semesters is allotted for the said subject. The first semester is for the thesis proposal phase and the last semester is for the completion of the whole paper and the final oral defence.

The subject has already been a part of the Teacher Education Curriculum since 2011. But as far as the researchers' observation is concerned and based on the experiences shared by their students, research is difficult and uninteresting to study (Shaukat, Siddiquah, Abiodullah \& Ali Akbar, 2014). Also, most students have negative attitudes and feelings toward research-related courses (Papanastasiou, 2006, Munir, Bolderston \& Fcamrt, 2009).

These attitudes affect achievement of students. Studies show that attitude impacts not only students' interests and participation in the subject they engage in but also their academic performance (Bibiet al., 2012). Thus, it is necessary to look into the self-efficacy level, anxiety level, and research attitudes of undergraduate students.

Studies have proven the necessity and effectiveness of self-efficacy of undergraduate students in research training (Rezaei \& Zamani-Mindashti, 2013). Self-efficacy refers to an individual perception of his or her degree of confidence of his or her capabilities to accomplish tasks and achieve goals. Self-efficacy represents an individual's confidence in performing a given behaviour (Pajares \& Urdan, 2006). Also, self-efficacy plays an important role in explaining other aspects of human functioning such as learning, achievement and self-regulation (Rezai, 2013). According to Self-Efficacy Theory, if individuals believe that they have the capacity to complete successfully a given behaviour, then they are more likely to engage in that behaviour (Rezaei \& Zamani-Mindashti, 2013).

There are few researches which focused on investigating the relationship between attitude on research and self-efficacy. However, studies conducted by Li (2012); Valle, Nunez, Cabanach, Gonzales-Pienda, Rodriguez, Rosario and Cerezo (2009); and Zamani-Miandashti, et al. (2013) revealed that there existed a relationship between effort regulation and university students' selfefficacy for performance and learning. The results showed that when students have a higher selfefficacy, they are more likely to put more efforts into their academic studies.

Attitude, on the other hand, is described by Fishbien and Ajzen (as cited in Belgrave \& Jules, 2013) is a learned predisposition to respond in a consistently favorable or unfavorable manner with respect to a given object. This proposes that condition existing within the teaching and learning situation or environment will have direct influence on the formulation of learners' attitudes both in cognitive and affective aspects. Furthermore, Belgrave and Jules (2013) enumerated the types of attitudes which learners possess and among them is their attitude towards research and about research learning in general.

Similarly, Amin (2017) conducted a study on the research attitude of post graduate students with respect to use and non-use of internet. The study revealed that post graduate students have favorable attitude towards research and significant difference on the attitude occurred among internet and non-internet users. On the other hand, Wang and Guo (2011) made a study on the influence of a required research component such as a thesis or research pproject on students' attitude towards research methods classes and their research posited that students can encounter major obstacles while studying in research methods classes and applying learned knowledge. Siddiqui and Ashmad (2015) conducted study on the research attitude of social science research scholars in relation to their motivation and self-concept. It revealed that achievement, motivation, and selfconcept played an important role in affecting the research attitude of scholars. Also, the study of Akyuz (2013) on the effect of research Methods Education Program on pre-service teachers' attitudes and anxieties showed that pre-service teachers' attitudes toward understanding educational 
research changed in a positive direction. Their anxiety level did not change after the theoretical courses related to educational research methods and statistics but reduced often when they carried out an educational research project by themselves.

Quite a number of researches had been conducted regarding attitude in relation to research. Shaukat, Siddiquah, Abiodullah and Ali (2014) found out that the students have positive attitudes towards research. Furthermore, males had significantly positive attitudes towards research than as compared with the females. Similarly, significant results were found on age, different programs of study, and university types.

Another study by Bazli, Israel, and Flynn (2014) compared the attitude of Medical Students on Research on University College Cork (UCC) and University Sains Malaysia (USM) which showed that medical students had good attitudes research attitude in both universities. Similar findings were revealed on the study on undergraduate medical students' attitude on research where time, availability of research mentors, formal teaching of research methodology, and the perception that the students would not receive appropriate acknowledgement for work put towards a research project appear to be barriers for students to become actively involved in research during medical school (Siemens, Punnen, Wong, and Jenji, 2010). Also according to Memarpour and Poostforoush (2015), medical science students in three schools of medicine, dentistry, and pharmacy showed a favourable knowledge on research, but their attitude toward the process ranked at below moderate. Undergraduate and single students showed a better attitude than residents. Females had a better knowledge of research than males.

Contrary to the findings on medical students' attitude on research is the finding of Mezzel and Zemliansky (2012) on Students' Pre Existing Attitude Toward Research Writing. Students enter college carrying with them a baggage of negative attitudes on research writing. Students tend to equate research work with looking for and reporting information and not with development and summarizing of new knowledge. Second, when completing assignment in a research course many students display more involvement and eagerness in primary research while continuing to show negative attitudes toward secondary research.

Meanwhile, it has been reported that education students enter research methods courses with feelings of stress and anxiety, although in most cases, they are not really aware of what research methods are all about (Murtonen \& Lehtiner, 2003; Wilson, 2001 as cited in Papanastasiou, 2006). Students incline to believe that research methods courses are overwhelming and that it is difficult to get through them. In addition, many students are not fully informed why research courses are necessary and what their usefulness will actually be in their teaching careers (Lodico, Spaulding, \&Voegtle, 2004; Pan \& Tang, 2005). Although this claim needs to be substantiated by further research, it has been already highlighted by Monahan (as cited in Papanastasiou, 2006) who found that education professionals who had completed a research methods course and experienced difficulties and anxiety, were not motivated to engage in research of their own or take additional research courses.

Recently, teaching and instruction in higher education is geared to becoming more researchdriven than just data-driven. Teachers are challenged to use evidences from different sources rather than just describing data or trends in their teaching. Thus, the importance of undertaking units in research methodology will provide pre-service teachers with the skills in research and reflective approach to address areas of need in the educational system. The researchers-being the research instructors of the third year pre-service teachers taking methods of research subject-see the need to look into the attitude of students toward research.

From the abovementioned studies, it appears that self-efficacy, anxiety, and research attitude play significant roles in learning and doing research. A theoretical model can be suggested to the success or failure of research teaching and learning. This model is represented in Figure 1. 


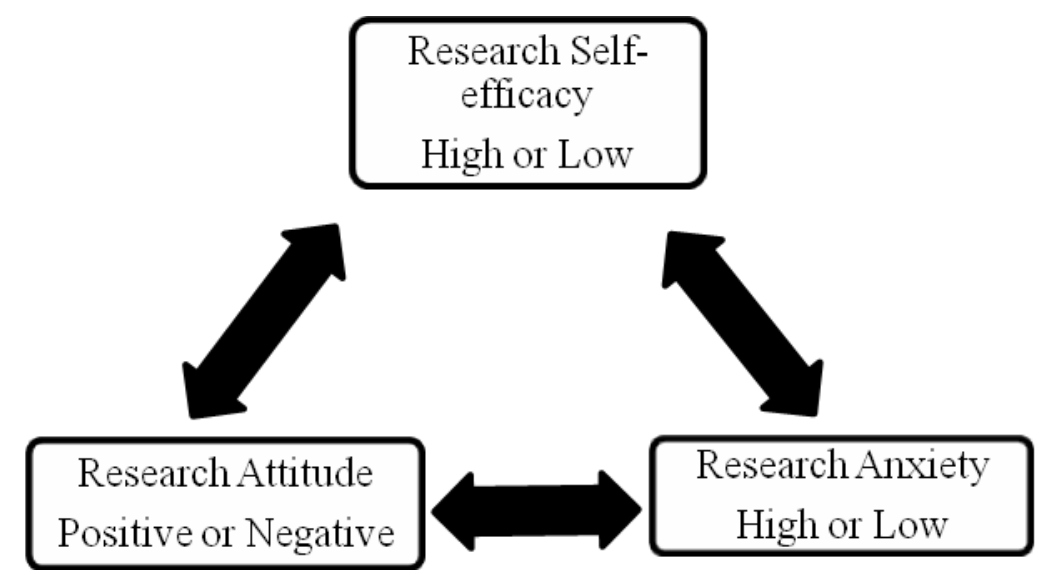

Figure 1: Relationship of self-efficacy, anxiety, and attitude towards research among education undergraduate students

The reason in conducting this study is to identify and describe the level of self-efficacy, level of anxiety, and attitude toward research of the fourth year pre-service teachers and to gather valuable information and seek new ways to stimulate research activities in Research Methods (ERESMETED) in Education classes. The study deems significant to research teachers because the data can serve as basis for intervention and improvement of students' performance in their ERESMETED subject. It will also guide the Teacher Education Department in the enhancement of the syllabus of the course at hand. The study will also provide a basis for further research involving all third year students taking up research subject.

Furthermore, it also sought to answer the following specific research questions:

1. What is the level of students' self-efficacy in research?

2. What is the level of anxiety experienced by students enrolled in methods of research in education class?

3. What is the students' attitude towards research?

4. Is there a significant relationship among self-efficacy, level of anxiety and research attitude of students?

5. Is there a significant difference among research self-efficacy, level of anxiety and research attitude of students according to their personal attributes?

6. What is the implication of the results of the study in the teaching of methods of research in education subject?

\section{Method}

\section{Participants}

The respondents of the study were the one hundred fifty four (154) or $82.79 \%$ of third year students enrolled in Research Methods in Education subject in the second semester of school year 20172018. The respondents were 121 females and 33 males. Furthermore, the respondents were grouped according to their areas of specialization.

\section{Design}

This study employed the descriptive cross-sectional method of research in determining the level of self-efficacy, level of anxiety and attitude towards research of the third year teacher-students of the School of Education. This type of study utilizes different groups of people who differ in the variable of interest, but share other characteristics such as socioeconomic status, educational background, and ethnicity. These methods are often used to make inferences about possible relationships or to gather preliminary data to support further research and experimentation (Trochim, 2006). Furthermore, the study also determined if the levels of self-efficacy and of anxiety among students 
are significantly related to their attitude toward research. Finally, the study also found out if students' self-efficacy, anxiety, and attitude toward research are significantly related to their personal attributes.

\section{Materials}

This study used a survey questionnaire developed by the researchers based on the questionnaire adapted from Ozturk Confirmatory Factor Analysis of the Educators' Attitudes toward Educational Scale and Papanastasiou's (2005) Attitude Toward Research (ATR) Scale. The questionnaire consists of four parts. The first part was the information on the participants' personal attributes such as gender and area of specialization. The second part consisted of the items on the research anxiety level and research attitude. In here, the respondents were asked to indicate whether they strongly agree (4), agree (3), disagree (2), strongly disagree (1) on the written statements. Part three of the questionnaire was the level of self-efficacy of students toward research adopted from the research made by Zamani-Miandashti, Rezaei in 2013. Their responses were according to the 5-point likert scale with a description of 1 - very low; 2- low, 3-average and 4- high. For its reliability, it was pilottested and got a reliability scale of 0.85 for research anxiety and 0.86 for attitude toward research.

Meanwhile, the self-efficacy questionnaire adopted from Zamani-Miandashti and Rezaei in 2013 had undergone validity and reliability tests. The content validity was assessed by experts in the field of research regarding the relevance of the items and the un-ambiguity of their formulation. Using Cronbach's alpha, 0.93 scale was calculated to establish internal consistency among the items in the questionnaire which is considered to be acceptable index for field research (Pallant, 2007).

\section{Procedure}

The researchers sought permission to the Dean of the School of Education to personally administer the questionnaires to the respondents of the study. Retrieval of questionnaires was done right after the respondents answered them.

Descriptive statistics such as frequency and mean were employed in tabulating data. Weighted mean was used in the analysis of the results on the research anxiety, research attitude and self-efficacy of students. To describe the level of self-efficacy, anxiety, and attitudes of students toward research, weighted mean was used. Pearson Product-Moment Correlation and one-way ANOVA were utilized to determine the relationship among the three variables: self-efficacy, level of anxiety and attitude toward research of the students as well as to determine the relationship of selfefficacy, level of anxiety, and attitude toward research of the students and their personal attributes.

The researchers made sure that the students were informed of the purpose of the study. The researchers also ensured the anonymity of the respondents by not asking their names. Furthermore, the information was only used for the purpose of this study and thus treated with utmost confidentiality.

\section{Results}

The level of research self-efficacy of teacher education students is average with an over-all mean rating of 2.74. The results show that the respondents have the ability to conduct research since all the 15 items displayed a verbal interpretation of "average". Furthermore, level of anxiety got a mean of 3.29 which means that the students have very high level of anxiety in doing research. However, they have positive attitude towards research as shown by the resulted mean of 2.96 (Table 1).

Table1: Level of Efficacy, Anxiety and Attitude Towards research of Pre-service Teachers

\begin{tabular}{|l|l|l|l|l|}
\hline & M & SD & Verbal Interpretation & Verbal Description \\
\hline Self-Efficacy & 2.74 & 0.54 & Average & \\
\hline Level of Anxiety & 3.29 & 0.41 & Strongly Agree & Very High \\
\hline Attitude & 2.96 & 0.49 & Agree & Positive \\
\hline
\end{tabular}

With regard to the relationship of research anxiety, research attitude, and research efficacy of teacher education students, the results show that there is no significant relationship between level of 
anxiety and level of self-efficacy towards research of the respondents. Likewise, the results also show that no significant relationship exists between research self-efficacy and attitude towards research and level of anxiety and attitude towards research of respondents. However, a significant relationship exists between respondents' self-efficacy and respondents' attitude towards research (Table 2).

Table2: Relationships of Research Anxiety, Research Attitude and Research Self-Efficacy of Students

\begin{tabular}{|l|l|l|l|l|}
\hline \multirow{2}{*}{ ANXIETY } & Pearson Correlation & 1 & -0.087 & -0.131 \\
\cline { 2 - 5 } & Sig. (2-tailed) & & 0.286 & 0.106 \\
\hline \multirow{2}{*}{ ATTITUDE } & Pearson Correlation & -0.087 & 1 & $.376^{* *}$ \\
\cline { 2 - 5 } & Sig. (2-tailed) & 0.286 & & 0.000 \\
\hline \multirow{2}{*}{ EFFICACY } & Pearson Correlation & -0.131 & $.376^{* *}$ & 1 \\
\cline { 2 - 5 } & Sig. (2-tailed) & 0.106 & 0.000 & \\
\hline
\end{tabular}

Regarding the comparison on research anxiety, research attitude, and research self-efficacy of the respondents, it was found out that there is no significant difference on the level of anxiety, level of efficacy, and attitude towards research in terms of the gender of the respondents since the computed $\mathrm{p}$ value for research anxiety of male and female is 0.77 ; research attitude of male and female is 0.39 and research self-efficacy of male and female is 0.38 (Table 3).

Table 3: Comparison on Research Anxiety, Research Attitude and Research Self-Efficacy of Male and Female Education Students

\begin{tabular}{|l|l|l|l|l|l|}
\hline \multicolumn{2}{|c|}{} & Mean & $\begin{array}{l}\text { Std. } \\
\text { Deviation }\end{array}$ & t computed & p value \\
\hline $\begin{array}{l}\text { Research } \\
\text { Anxiety }\end{array}$ & MALE & 3.31 & 0.49 & 0.33 & 0.77 \\
\cline { 2 - 4 } $\begin{array}{l}\text { Research } \\
\text { Attitude }\end{array}$ & FEMALE & 3.28 & 0.39 & -0.86 & 0.39 \\
\cline { 2 - 4 } $\begin{array}{l}\text { Research } \\
\text { Self-Efficacy }\end{array}$ & FEMALE & 2.89 & 0.67 & -0.88 & 0.38 \\
\cline { 2 - 4 } & MELE & 2.67 & 0.43 & & \\
\hline
\end{tabular}

Moreover, on the comparison on research anxiety, research attitude, and research selfefficacy of teacher education students according to their area of specialization, the results show that there is no significant difference between research anxiety and efficacy when compared to their area of specialization. However, there is a significant difference in the research attitudes of the respondents according to their area of specialization with a p value of .007 (Table 4).

Table 4: Comparison on Research Anxiety, Research Attitude and Research Self-Efficacy of Education Students according to Area of Specialization

\begin{tabular}{|l|l|l|l|l|l|l|}
\hline \multicolumn{2}{|c|}{} & Sum of Squares & df & Mean Square & F & Sig. \\
\hline \multirow{4}{*}{ ANXIETY } & Between Groups & 1.548 & 8 & .193 & 1.140 & .340 \\
\cline { 2 - 7 } & Within Groups & 24.432 & 144 & .170 & & \\
\cline { 2 - 7 } & Total & 25.980 & 152 & & & \\
\hline \multirow{5}{*}{ ETTITUDE } & Between Groups & 4.903 & 8 & .613 & 2.796 & .007 \\
\cline { 2 - 7 } & Within Groups & 31.563 & 144 & .219 & & \\
\cline { 2 - 7 } & Total & 36.465 & 152 & & & \\
\hline \multirow{5}{*}{ EFFICACY } & Between Groups & 4.288 & 8 & .536 & & \\
\cline { 2 - 7 } & Within Groups & 39.535 & 144 & .275 & & \\
\cline { 2 - 7 } & Total & 43.824 & 152 & & & \\
\hline
\end{tabular}

At .05 level of significance 


\section{Discussion}

The results of the study revealed that the third year education students taking Research Methods in Education have a high level of anxiety in conducting research. But despite their high level of anxiety in research, the respondents manifested a favourable or positive attitude toward research. With regard to the level of research self-efficacy, the teacher education students rated themselves to have an average self-efficacy or one's ability to perform specific research activities.

Similar to this finding is the result of the study of Belgave and Jules (2015) that validated the hypothesis i.e. students' perceptions of the functionality of research and the meaningful application to real-life situations result in a positive attitude towards research. While the findings of Butt and Ara (2013) showed that the teacher opinions about the research usefulness, research anxiety, positive attitudes, relevance to life, and research difficulty showed a low-level attitude toward research. The student teachers believed that research is a difficult process as it is hardly useful for their professional life, having very low relevance to their lives thereby increasing their anxiety level.

On the hypothesis that there is a significant relationship among self-efficacy, level of anxiety, and research attitude of students the results of the study revealed that there is a positive relationship that exists between teacher education students' self-efficacy and respondents attitude toward research. This indicates that pre-service teachers with positive attitude toward research are more confident in their ability to conduct research. While on level of self-efficacy and research anxiety, no significant relationship was noted. However, this result contradicted the result of the study made by Razavi, et al in 2017 when their finding said that there is a significant negative relationship between research anxiety and self-efficacy of students at the Islamic Azad University (Babol Branch).

Similarly, the hypothesis that there is a significant relationship between level of anxiety and attitude toward research was rejected. It means that the ability to perform research task is not related to the level of anxiety of participants. Likewise, the level of anxiety in research does not affect their attitude in the conduct of research. These findings are consistent with the results of the study of Zamani-Miandashti (2013) and Rezaei (2013) that suggest that students' research self-efficacy was negatively correlated with their research anxiety. It was also found that there was a positive and significant relationship between students' attitudes toward research with their self-efficacy.

The research found out that there is no significant difference on the level of anxiety, level of efficacy, and attitude towards research in terms of the sex of the respondents. It means that the gender of the respondents has no effect on research anxiety, efficacy, and attitude of teacher education students. The findings support that of the study of Bandele and Adebule (2013) that reveal the patterns of graduating students' attitude to research work irrespective of the gender are very similar.

The study provided findings on the pre-service teachers' research self-efficacy, level of anxiety, and attitude towards research and its relationship to their personal attribute were investigated. While third year education students have high level of anxiety, with favourable or positive attitude on research and average self-efficacy on research, these variables do not correlate with gender and area of specialization except for research attitude that correlate to the major area of specialization. Also, the higher the research self-efficacy of the participants is, the favourable their attitude toward research is as well; while research anxiety does not relate to ability of the participants in conducting research. Further, research attitude does not contribute to anxiety level of the teacher education students. The findings supported the research made by Siamian, et al. (2016) which showed that there was insignificant difference between the variables of age, gender and level of education and the attitude of students towards research.

\section{Conclusion}

In view of the findings and conclusions given, it is therefore recommended that Research Methods in Education professors continually improve the teaching and learning process in the mentioned subject so as to sustain the positive attitude of students toward research. There should be program and activities for students taking up the subject for them to improve their research self-efficacy. Also, with the results of the study, the School of Education may reinforce the importance of the subject Research Methods in Education and its relevance to the professional life of pre-service 
teachers. It is also encouraged that professors tailor the course's academic process to address the issues related to undergraduate research attitude, anxiety, and self-efficacy.

\section{References}

Akyuz, G. (2013). Reflections from Research Methods Education Program: Effect on pre-service teachers' attitudes and anxieties. New Horizons in Education, 61(2), 1-12.

Amin, S. (2017). A study of research attitude and stream differences among post graduate students with respect to use and non-use of Internet. International Journal of Development Research, 7(1).

Bandele, S.O., and Adebule, S. O. (2013). Patterns of University graduating students' attitude to research work. International Journal of Educational Research and Technology, 4(3), 98-103.

Bazli M.Y., Israel, M., Flyn, O. S. (2014). Study on medical students' attitude towards research activities between University College Cork and USM. Elsevier Procedia-Social and Behavioral Sciences, 116 (21).

Belgrave , K., and Jules, J. (2013). Students' Attitudes towards Research Applying Best Practice Principles through a Student-Centred Approach. Students Attitudes towards Research, 1-18. Retrieved from http://uwispace.sta.uwi.edu/dspace/bitstream/handle/2139/40093/Students'\%20Attitudes\%20Tow ards $\% 20$ Research $\% 20$ Belgrave $\% 20$ and $\% 20 \mathrm{Jules}$.pdf?sequence $=1$.

Bibi, F., Iqbal, H. M., and Majid N. (2012). Attitude of prospective teachers towards research: Implications for teacher education in Pakistan. Contemporary Educational Researches Journal, 1(1), 8-14.

Brown, H. D. (2007). Principles of language learning and teaching. New York, NY: Pearson Education Inc.

Butt, I. H., and Shams, J. A. (2013). Master in Education Student Attitudes towards Research: A Comparison between two Public Sector Universities in Punjab. South Asian Studies A Research Journal of South Asian Studies, 28(1), 97-105.

Cheetham, J. (2007). Disciplinary research agendas and institutional arrangements for evaluation research. International Journal of Social Welfare, 7 (2).

Creswell, J. (2008). Educational research: planning, conducting and evaluating quantitative and qualitative research. Pearson/ Merrill Prentice Hall.

Dinther, M. V., Dochy, F. \& Segers, M. (2011). Factors affecting students' self-efficacy in Higher education. Educational Research Review, 6(1), 95-108.

Etzkowitz, H. (2003). Research groups as 'quasi- firms': the invention of the entrepreneurial University. Research Policy, 32(1), 109-121.

Gecas, V. (2004). Self-agency and the life course. In J. T. Mortimer \& M. J. Shanahan (Eds.), Handbook of the life course (pp. 369-390). New York: Springer Science + Business Media, LLC.

Li, L. (2012). A study of the attitude, self-efficacy, effort and academic achievement of City U students towards research methods and statistics. SS Student E-Journal ,1(1), 154-183.

Lodico, M., Spaulding, D. \& Voegtle, K. (2010). Methods in educational research: From theory to practice, 2nd Edition. San Francisco, CA: Jossey-Bass.

Lunenburg, F. (2011). Self-efficacy in the workplace: implications for motivation and performance. International Journal of Management, Business, and Administration, 14(1).

Memarpour, M., and Poostforoush, F. (2015). Evaluation of attitude to, knowledge of and barriers toward research among medical science students. Asia Pacific of Farm Medicine, 14(1).

Mezzel, D., and Zemliansky P. (2012). Students' pre existing attitude towards research writing. Research Writing in First Year Composition and Across Discipline.

Munir, N., Bolderston, A., \& Fcamrt, M. (2009). Perceptions and attitudes toward conducting research: A nuclear medicine student perspective. Journal of Medical Imaging and Radiation Sciences, 40(1), 183-189.

Onwuegbuzie, A. J., \& Seaman, M. (1995). The effect of time constraints and statistics test anxiety on statistics achievement. Journal of Experimental Education, 63 (2), 115-124.

Onwuegbuzie, A. J., \& Wilson, V. A. (2003). Statistics Anxiety: Nature, etiology, antecedents, effects, and treatments--a comprehensive review of the literature. Teaching in Higher Education, 8(2), 195-209.

Pajares, F., \& Urdan, T. (2006). Foreword. In F. Pajares and T. Urdan (Eds.), Self-efficacy beliefs of adolescents (pp. ix-xii). Greenwich, CT: Information Age Publishing.

Pan, W., \& Tang, M. (2005). Students' perceptions on factors of statistics anxiety and instructional strategies. Journal of Instructional Psychology, 32(3), 205-214.

Papanastasiou, E. C. (2005). Factor structure of the attitudes toward research scale. Statistics Education Research Journal, 4(1), 16-26.

Razavi, S. A., Shahrabi, A., \& Siamian, H. (2017). The relationship between research anxiety and self-efficacy. Materia socio-medica, 29(4), 247-250.

Rezei, M., and Zamani, M. (2013). The relationship between research self-efficacy, research anxiety and attitude toward research: A study of the agricultural graduate students. Journal of Educational and Instructional Studies in the World, 3(4).

Shaukat, S., Siddiquah, A., Abiodullah, M., and Ali Akbar, R. (2014). Postgraduate students' attitudes towards research. Bulletin of Education and Researc, 36(1), 111-122.

Siamian, H., Mahmoudi, R., Habibi, F., Latifi, M., \& Zare-Gavgani, V. (2016). Students' attitudes towards Research at Mazandaran University of Medical Sciences in 2015. Materia socio-medica, 28(6), 468-472.

Stern, H. H. (2009). Fundamental concepts of language teaching. New York, NY: Oxford 
Snyder, C. R., \& Lopez, S. J. (2007). Positive psychology: The scientific and practical explorations of human strengths. Thousand Oaks, CA: Sage.

Trigwell, R. \& Goddet, H. (2005).The research experience of postgraduate research students at the University of Oxford Institute for the Advancement of University Learning. Retrieved from http://www.learning.ox.ac.uk/media/global/wwwadminoxacuk/localsites/oxfordlearninginstitute/d ocuments/overview/rsv/The_Research_Experience.pdf.

Trochim, W. M. K. (2006). Time in research. Web Center for Social Research Methods. Retrieved from http://www.socialresearchmethods.net/kb/timedim.php.

Valle, A., Nunez, J. C., Cabanach, R. G., Gonzalez-Pienda, J. A., Rodríguez, S., Rosário, P., \& Cerezo, R. (2009). Academic goals and learning quality in higher education students. The Spanish journal of psychology, 12(01), 96-105.

Van der Bijl, J. J., \& Shortridge-Baggett, L. M. (2002). The theory and measurement of the self-efficacy construct. In E. A. Lentz \& L. M. Shortridge-Baggett (Eds.), Self-efficacy in nursing: Research and measurement perspectives (pp. 9-28).

Wang, C., \& Guo, Y. J.(2011). Counseling students' attitudes toward research methods class. Retrieved from http://www.wjeis.org/FileUpload/ds217232/File/09c.rezaei.pdf.

Wayne, P. M., Hammerschleg, R., German, J. S., Chapman, T. (2011). Attitude and interest toward research among students of two college of acupuncture and oriental medicine. PubliMED: PMC US Library of Medicine.National Institute of Health.

Zamani, N., and Rezaei, M. (2013). The relationship between research self-efficacy, research anxiety and attitude towards research: A study of Agricultural Graduate students. Journal of Educational and Instructional Studies in the World. 3(4, 2146-7463. 